\title{
Cultural Imperialism in the Discourse of Globalization (Subjective Factors)
}

\author{
Nina Zrazhevska \\ Ukrainian Catholic University, 17 st. Ilariona Sventsitskoho, Lviv, 79011, Ukraine \\ Corresponding author's e-mail address: foxiua@yahoo.com
}

\begin{abstract}
In this research the subjective reasons for the expansion of global culture in local cultures are explored. The main objective is to analyze the subjective factors of the cultural imperialism and to show that psychological, marketing and technological factors are no less important than ideological and economic reasons of globalization.

The methodology of research is based on cultural approach to the process of cultural imperialism, which describes at least four main scenarios of globalization. The first scenario is a global homogenization and cultural unification under the influence of "cultural imperialism". The second scenario, "peripheral corruption" is the expansion of the Western culture to the peripheral segments in a global world, where the peripheral cultures filtrate and adapt the global cultural products. The third scenario is a "mosaic" culture of the isolated competing cultures of the hostile civilizations. The fourth scenario is an open egalitarian world with intense cultural exchange.

We conclude that the subjective aspects of cultural globalization relate to the production of discourse, in which great narratives are challenged by the diversity of consumption practices. Given that globalization policy involves multiculturalism, the multiplicity of identities triggered by the virtualization technologies causes the new forms of cultural interaction and allows playing with different cultural contexts. The cultural imperialism is caused by the interpenetration of cultures resulting from the multicultural policy of the Western countries, that creates the effect of selfidentity within the global cultural discourse.

Cultural imperialism takes place due to the media-globalization, since the media-culture dominates in contemporary cultural discourse. In the contemporary socio-cultural environment, the media acquired global significance and technologically expanded human capabilities. A distinctive feature of the modern technologies is their potential to not only extend human capabilities, but also to significantly influence humanity, change human's perception of the world and of oneself.

Based on the cultural approach to the problem of globalization, we substantiate that in contemporary Ukraine the second scenario of cultural imperialism ("peripheral corruption") dominates. It filtrates the globalized cultural products and adapts them for itself.
\end{abstract}

KEYWORDS: cultural imperialism, globalization, subjective factors of globalization, media globalization, cultural analysis. 


\section{Культурний імперіалізм у дискурсі глобалізації (суб'сктивні фактори)}

Зражевська Ніна Іванівна, Украӥнський католицький університет, професор, доктор наук із соціальних комунікацій

\section{Резюме}

У статті розглянуті суб’єктивні причини експансії глобальної культури в локальні культури. Головна мета цього дослідження - проаналізувати суб'єктивні фактори культурного імперіалізму та довести, що психологічні, маркетингові, технологічні причини $є$ не менш важливими, ніж ідеологічні та економічні причини глобалізації. Отже, суб'єктивними аспектами культурної глобалізації вважаємо виробництво дискурсу, в якому великим наративам зроблено виклик різноманітністю практик споживання. Культурний імперіалізм відбувається завдяки «медіаглобалізації», оскільки саме медіакультура є панівною в сучасному культурному дискурсі.

Ключові слова: культурний імперіалізм, глобалізація, суб'єктивні фактори глобалізаціі, медіаглобалізація, культурологічний аналіз.

Зражевская Н.И. Культурный империализм в дискурсе глобализации (субъективные факторы).

Резюме. В статье рассмотрены субъективные причины экспансии глобальной культуры в локальные культуры. Главная цель этого исследования - проанализировать субъективные факторы культурного империализма и доказать, что психологические, маркетинговые, технологические причины не менее важны, чем идеологические и экономические причины глобализации. Таким образом, субъективными аспектами культурной глобализации считаем производство дискурса, в котором большим нарративам сделан вызов разнообразием практик потребления. Культурный империализм происходит благодаря «медиаглобализации», поскольку именно медиакультура является господствующей в современном культурном дискурсе.

Ключевые слова: культурный империализм, глобализация, субъективные факторы глобализации, медиаглобализация, культурологический анализ.

\section{1. Вступ}

Культурний імперіалізм прийнято пов’язувати 3 процесами глобалізації. Проте цей зв'язок не такий простий, як може здатися, і він не був би таким потужним без врахування суб'єктивних причин експансії мейнстрим-культури в інші локальні культури. Сучасна мейнстрим-культура спрямована на виробництво культурних продуктів, що повинні конкурувати в глобальному середовищі. Важливою проблемою є й те, якими засобами медіа- 
культура переконує людей змінити свою думку і самих себе у напрямку домінантної соціальної системи та політичної, ідеологічної позиції, репрезентації. Аналіз культурного імперіалізму набуває особливої актуальності, оскільки останнім часом американська медіакультура визначає панівні форми глобального медіаспоживання. В українських реаліях до цього додається вплив потужної медіаіндустрії Росії.

Перебуваючи в процесі глобалізації, сучасна культура як медіакультура має потужний технологічний потенціал для створення такого типу культури, яка задовольняє різні смаки і вподобання. Дійсно, без врахування технологій неможливо створювати конкурентоспроможний продукт у медіапросторі. Сучасна людина хоче споживати якісний і технологічно досконалий продукт. Виграє лише той виробник, хто може дати такий продукт аудиторії. Культурні індустрії якраз працюють у цьому напрямку.

До продуктів культурної індустрії відносимо такі: телевізійна і радіоіндустрія, включно 3 кабельним та супутниковим TV; індустрія виробництва кінофільмів, з урахуванням відео (DVD), а також телевізійних фільмів; інтернет-індустрія, зокрема всі форми «Net Art» i «Net Culture», а також виробництво сайтів, порталів та інших форматів колективної й групової комунікації; музична індустрія: звукозапис (не тільки власне музична), поширення записів з усіма формами контролю та дотримання прав, а також різні види «Live Performance»; видавничий бізнес, що охоплює виробництво книг, компакт-дисків, інформаційних баз, а також у певній частині журналів і газет, а також супутні йому послуги; різного роду освітні та ігрові індустрії (іноді тут використовують узагальнену назву «Edutainment».

Крім цього, слід зазначити і такі сегменти як: індустрія реклами і маркетингу з усіма, що належать їй, технологіями формування міського та регіонального середовища у тій частині, де вже сформувалася соціально-індустріальна модель відтворення й поширення цієї діяльності - клуби, масові акції та інші форми наповнення способу життя, особливо в урбаністичних центрах, «творчі індустрії» у вузькому сенсі.

Мета статті. У контексті суб'єктивної теорії глобалізації, яку ми намагаємося обгрунтувати, феномен культурних індустрій обумовлений «чарівністю» технологій у широкому змісті цього слова - не просто як технологічної суті культурних продуктів, а як комунікативної і психологічної складової, що є невід'ємною від сучасного культурного дискурсу. Голова мета цього дослідження - довести, що психологічні, маркетингові,технологічні фактори є не менш важливими, ніж ідеологічні та економічні причини глобалізації. Аналіз так званих «суб'єктивних форм» як ключових понять в розумінні культурного імперіалізму дозволить розкрити внутрішні механізми і тенденції, що об'єднують культури і нації, держави і цивілізації.

\section{2. Методи дослідження}

Теорія глобалізації в рамках традиційного історико-культурного і соціологічного методів здебільшого пояснює глобалізацію експансією американської культури (експансія капіталістичної економіки, втрата національними державами контролю, зміна локального середовища, складна ідентифікація). Класифікацію і розвиток теорії глобалізації добре репрезентує стаття М. Кравчука «Концептуальна еволюція теорій глобалізації» [1]. Ми ж зупинимося на тих теоріях глобалізації, що можна назвати постглобалізаційними, які розглядають локальні, глокальні і суб'єктивні аспекти культурного імперіалізму.

Особливої уваги заслуговує в цьому контексті соціологія Е. Гідденса, де він зробив спробу створити моністичне уявлення про соціальну реальність, в якому обгрунтував опозицію суб'єктивного та структурного аспектів соціального розвитку. Вчений розглядає глобалізацію як безпосереднє продовження модернізації, вважаючи, що сучасності (Modernity) внутрішньо притаманна глобалізація. Цікавою є також концепція М. Уотерса, 
якій ввів поняття “пост-глобалізації”, що може також бути пояснена в термінах «гіперглобалізація» - експансія соціальних процесів у нові форми просторовості, і як деглобалізація - редукція дійсної просторовості соціальних процесів [1].

У цій статті ми також використовуємо культурологічний підхід до процесів культурного імперіалізму, який описує принаймні чотири основні сценарії наслідків глобалізації.

Перший - це глобальна гомогенізація, культурна уніфікація під впливом «культурного імперіалізму».

Другий - сценарій «периферійної корупції» - розкладання західної культури на периферійні сегменти в глобальному світі, коли периферійні культури відфільтровують і залишають культурні продукти низького рівня.

Третій сценарій - мозаїчна культура - культура замкнених, конкуруючих культур ворожих цивілізацій.

Четвертий сценарій - світ егалітарний відкритий з інтенсивним культурним обміном (Маріо Варгас Льоса) [2, 350].

Культурологічний підхід не оминає і постмодерністську рефлексію, адже фрагментація і відсутність центру, усеядність і плюралізм культури постмодерну поруч з процесами культурного імперіалізму формує особливе культурне середовище.

С. Удовік, перераховуючи концепції глобалізації [2, 348], вказує, що жодна 3 них не пояснює суті глобалізації $[2,350]$. Дійсно, проблема глобалізації повинна бути досліджена 3 різних боків і різними методами. В умовах медіакультури як мета культури сучасності саме медійна і комунікативна теорія роз'яснює глибинні, сутнісні аспекти культурного імперіалізму.

Відомий дослідник медіа Д. Бігнелл стверджує, що медійна теорія, в аспекті глобалізації залучає проблему індивідуального, локального, але залишається невпевненою у тому, яким чином здійснюється такий індивідуальний вибір, і як такий вибір може бути пов'язаний з розумінням соціальних сил, інститутів тощо [3, 166].

Медійна теорія в питанні культурного імперіалізму рухається від обговорення структурних детермінант культури (наприклад теорії глобалізації) до суб'єктивного фактора (вибір, пошуки індивідуального). Сучасні тенденції адептів культурної автономії репрезентують різні механізми і техніки опору культурному імперіалізму, включно 3 теоріями i практиками антиглобалізму, мультикультуралізму тощо.

У цьому контексті інколи важко пояснити, що культура та ідеологія - це різні явища, що виступати за культурну автономію і одночасно користуватися айфонами та інтернетом - дилема, яка може бути розв'язана лише тоді, коли культурний імперіалізм розглянути в дискурсі глобалізації як явища цивілізаційного (технологічного), з одного боку, і з іншого, як явища психологічного (комунікативного).

У дослідженні явища глобалізації у формуванні культурного імперіалізму традиційні історичні і соціологічні методи втрачають свою актуальність, оскільки мають справу 3 феноменом досі не осмисленим, який не має окресленої парадигми і зрозумілого дискурcy.

Соціологічні й історичні методи дослідження поступаються місцем іншим методам роботи 3 культурними текстами - етнографічним (якісні методи), феноменологічним, семіотичним, герменевтичним тощо. Усе більшого значення набувають методи, що використовують так звані культурні дослідження з усім спектром методів постмодернізму, починаючи від структуралізму і семіотики, закінчуючи теоріями фемінізму тощо: Ентоні Гідденс (що перше, структура соціального життя, чи особистість), Зігмунд Бауман (плинна сучасність), А. Аппадурай (взаємозв'язок глобального і локального), Скотт Леш (скорочення часу, посилення нагляду), Д. Келлнер (медіакультура як панівна культура сучасності), Ж. Бодріяр (сучасна культура як симулякр) тощо. 


\section{3. Результати і обговорення}

Ми вже наголошували, що об’єктом культурних досліджень постає «соціальне життя суб'єктивних форм». Тому інтерпретація культури як діяльності з виробництва свідомості, «суб’єктивні форми», у які ми вкладаємо наше життя, це основна мета такого аналізу.

Ще класики Франкфуртської школи Т. Адорно і М. Хоркхаймер вважали, що дорога до культурної гегемонії здійснюється через психологічну обробку, а не через філософський диспут. До концепції культурного імперіалізму слід долучити термін «медіаімперіалізм», що найбільше відповідає сучасним тенденціям глобалізації. Унаслідок розповсюджуваних 3МІ культурних та інших тенденцій, культура змушена грати за заздалегідь встановленим правилам, іменованими кон'юнктурою ринку. Дійсно, той сегмент культурної політики, який реалізується засобами масової інформації, зазвичай відповідає інтересам (медіамагнатів), а також державі, оскільки інтереси бізнес-еліти в цьому відношенні часто тотожні інтересам і цілям держави. Мейнстрим-культура, що підтримує статус-кво, активно використовує медіа як головний інструмент конструювання соціальної дійсності і культури в цілому. Мета цього процесу - досягнення суспільної згоди та вироблення медіапродукту, що задовольняє широку аудиторію в межах цілого світу.

Як зазначає Г. Філімонов: «Концепція «медіаімперіалізму» швидко знайшла прихильників в рядках американських вчених. Уотергейтський скандал, пов'язаний з передвиборчою кампанією Р. Никсона, спровокував підозру в існуванні таємного зв'язку між урядом і 3MI, а також у зловживанні виконавчою владою своїми службовими повноваженнями [4]. У ряді своїх праць дослідник ЗМІ і пов'язаних з ними актуальних проблем Г. Шиллер визначив наявність тісного зв'язку між вищими діловими колами, військовими, і урядом 3 одного боку, і т.зв. «Маніпуляторами умів» («mind managers»), тобто главами провідних американських 3MI, з іншого. Таким чином, між цими двома силами, згідно Шиллеру, є таємний взаємозв'язок, що базується на секретній змові, метою якої є контроль і маніпуляція умами як усередині країни, так і за ії межами [5].

Головним чинником культурного імперіалізму - постає медіаімперіалізм. Теоретик масових комунікацій з Канади I. Макфейл об'єднує феномен «медіаімперіалізму» в поняття «електронний колоніалізм», що представляє собою модель «залежних відносин, заснованих на імпорті великих обсягів інформації, комунікаційного обладнання та програмного забезпечення, що опосередкованим чином встановлює ряд зарубіжних норм, цінностей $\mathrm{i}$ очікувань, в тій чи іншій мірі змінюють внутрішню культуру і процеси соціалізації» [6, 18]. У реальну повсякденність входить медіатизована гіперреальність, сюрреалізм шоу: гламурний стиль життя, манера спілкуватися, зняття табу, акцент на драмах приватного життя тощо.

Саме завдяки медіа відбувається процес стереотипізації свідомості, оскільки людина в сучасному світі є «медіатизованою людиною».

Аналізуючи стереотипи масової свідомості, М. Бутиріна використовує поняття «ефект» як результат дії окремого комунікативного повідомлення - «...це абсолютна величина, яка може визначатися на різних рівнях, приміром,...виникнення інтересу до певного суспільного явища чи факту історії...» [7, 209]. Як зазначає Т. Крайнікова : «Медіапродукти активно поширюють стереотипи у формі стійких образів. Плакати, афоризми 3 текстів, популярні та знакові пісні, упізнавані кадри тощо - у цих вербальних, візуальних, аудіальних формах згущуються, фіксуються і вірусно поширюються стереотипні уявлення». [8, 168]. «Стереотипізація мислення споживача як тотальна маніпуляція - це тільки один бік медалі. Проблема полягає ще й в тому, що медіаконсьюмери творені медіастереотипи «підчеплюють» добровільно» $[8,170]$.

Отже, методи реконструкції стереотипів свідомості, закладені в культурній традиції і репрезентовані в різноманітних артефактах, стають основним інструментом культурних 
студій, що покликані розкрити здебільшого суб'єктивні причини культурного імперіалізму.

Як відомо, теза культурного імперіалізму, що почала активно розвиватися в 19501960-х рр., звертала недостатньо уваги на локальні і національні особливості медіаорганізацій і медіаспоживання. Також недостатньо уваги було приділено регіональним потокам.

Як вказує М. Кравчук: «3 кінця 1980-х років більшість досліджень теорії змін було зосереджено на новому генеральному напрямку - розробці теорій глобалізації. 1990 року виходить програмний збірник статей “Глобальна культура", у якому опубліковано роботи провідних теоретиків цієї проблеми І. Уоллерстайна, М. Арчера, Р. Робертсона, М. Фезерстоуна, А. Аппадурая, Б. Тернера й ін. 3 цього часу одна за одною з'являються фундаментальні монографії про глобалізацію Л. Склера, Р. Робертсона, О. Іанні , М. Уотерса, А. Аппадурая, У. Бека та інших дослідників» [1]. Зміст концептуального повороту, який відбувся в суспільних науках, чітко сформульовано у вступі М. Фезерстоуна і С. Леша до збірника статей «Глобальні сучасності» (Global Modernities): дискурс глобалізації виник як «спадкоємець дебатів про сучасність (modernity) і постсучасність» [9]. У мультикультурних локальних співтовариствах категорії «міжнародні відносини», «зіткнення цивілізацій”, «транснаціональнакорпорація» стають практичними категоріями взаємодії. У цьому випадку термін «глобальне» означає не тільки «інтернаціональне», але й «субнаціональне» $\mathrm{i}$ навіть «локальне» у тій мірі, у якій останнє глобалізує-перетворює повсякденне життя людей у переживання глобального. Щоб підкреслити дворівневість глобалізації, співвідносність і взаємопроникнення глобального і локального, сполучення тенденцій догомогенності і гетерогенності, Р. Робертсон вводить спеціальний термін «глокалізація» [9].

Зрозуміло, що синергія між окремими сферами виробництва обладнання, провайдерами контенту, та програмами, телекорпораціями тощо забезпечує панування на ринку декількох великих корпорацій, в основному американських і японських (як Тайм-Уорнер, або Сони), так щоб розповсюдження глобалізації до американізації модифікувало силу корпоративного, а не національного контролю над медіа.

У той час як модернізація передбачає глобальне розповсюдження ідеології (західний капіталізм), глобалізація з іншого боку описує також маркетингові мережеві технології споживання, через які продукти розповсюджують, хоча це не означає, що глобальні медіапродукти розповсюджують конкретну ідеологію. Іншими словами культурна глобалізація - це ідеологічний інструмент з одного боку, з іншого - це маркетинговий інструмент, що спирається на закони ринку.

А. Аппадурай стверджував, що є різні медіаландшафти, техноландшафти, фінансоландшафти, ідеологоландшафти і етноландшафти, і хоч глобалізація $є$ широко розповсюдженим постмодерністським феноменом, вона відрізняється від модернізації і сучасності спільністю універсальної культури і культурною фрагментацією в різних локальних і дискурсивних формах $[10,295-310]$. Іншими словами постмодерністський характер явища глобалізації пояснюється не тільки фрагментацією, плинністю і мультикультурністю, а існує в повсякденних практиках споживання і обміну.

Панує точка зору, що глобалізацію спрямовують і регулюють особливі інститути в суспільствах і країнах, що глобалізація і сама $є$ політичною ідеєю, а не автономним і універсальним процесом, який спирається на випадкові і мінливі умови, і яка зустрічає опір або відмову в результаті політичного вибору. Як вказує Аппадурай, глобальні ринки регулюються контрактами і законом, і грунтуються на поняттях: праця, гроші, прибуток і обмін, які знайомі нам з аналізу К. Маркса. Але Аппадурай підкреслює також феномен участі споживачів у виробництві як втілення ідеї «дарування». Така ідея лежить, наприклад, в основі відомого проекту «вікіноміка» Д. Тапскотта і Е. Уїльямса [11], суть якої автори вбачають у тому, що ресурси величезної кількості людей за допомогою технології «вікі», блогів і соціальних мереж дозволяють заснувати нову економіку, яка буде характеризува- 
тися співпрацею споживачів і корпорацій. На їхню думку, найбільш просунуті споживачі, що створюють власні продукти і здатні до самоорганізації, фактично є «підприємцями». Однак ідеї Д. Тапскотт і Е. Уїльямса якраз відображають нову філософію, точніше, нову ідеологію бізнесу, коли контракти, які базуються на ідеї соціального, є марними, якщо не підтримані вірою в взаємодію і довіру між учасниками. Таким чином, капіталістичний ринок може існувати, коли є певна символічна і соціальна солідарність в суспільстві, та певні соціальні бонуси не перешкоджають тріумфу капіталістичного ринку. Вільний ринок і глобалізація часто розглядаються як природні факти, вони грунтуються на політичних рішеннях про дерегуляцію, змагання та соціальні цінності в основному національних держав. Держави й організації дерегулюють і заохочують глобалізацію, а також регулюють i захищають своїх громадян від неї. Держава і нація грають важливу роль у визначені ступеня влади над культурою, яку може мати медіаглобалізація.

Але в контексті глобалізаціонної теорії поняття соціального і нації стає проблематичним. Розширення телевізійної технології та телеперегляду дає підстави для соціологічних досліджень сучасності, для дослідження наслідків нових культурних форм суспільства, що розглядаються як окремі і методологічно визначені утворення. Ентоні Гідденс стверджує, що концепція суспільства як одиниці, обмеженої в часі і просторі, стає зайвою в подібних контекстах, і що нові форми соціальної організації затьмарили традиційні суспільства [12]. Він розглядає глобалізацію не стільки як явище політики або економіки, а більше як основу життя сучасної людини, способу іï існування, поглядів тощо. Сучасність під впливом новітніх технологій не стає стабільнішою, навпаки світ стає ще більш некерованим, «плинним».

Дискурси навколо широкомасштабного процесу глобалізації з їх інтересом до транснаціональних і до національних медіатехнологій і потокам дистрибуції роз'єднують точки зору теорії суб'єктності і теорії споживання. Скотт Леш пише, що дискурсивний режим сучасності, надає пріоритет візуальному або вигаданому, акумулюючи матеріал з повсякденного життя, він протистоїть раціональному і сприяє зануренню глядача в культурний досвід, що веде до анестезії повсякденного життя. Споживання стає ресурсом для створення миттєвих і множинних особистостей. що контрастують з споживацьким вибором, зробленим іншими соціальними групами. Майк Фезерстон, так само, як і Скотт Леш, асоціює цей зсув у постмодерн з рекламістською та промоушенською культурою, оскільки остання включає естетизацію повсякденних товарів та досвіду, і домінування знаків та образів у досвіді (міських і в основному західних) соціальних суб'єктів. Стосовно постмодерністської суб'єктивності існує паралель з точкою зору Фредеріка Джеймісона. Бігнелл зазначає: «відчудження суб'єкта витісняється його фрагментацією», де відчужений суб'єкт модернізму змінений на перехідну ідентичність, яка створена такими складниками, як ставлення до речей як до рекламних образів [3, 169]. Фезерстон слідом за працями Пьера Бурдьє розглядає цю явну свободу з обережністю, доводячи, що їі функція - дати можливість мати різні смаки, якими легітимні члени середнього класу відрізняються один від одного і від менш привілейованих соціальних груп. Позитивна риса цієї ситуації - можливість гри 3 ідентичністю, на відміну від того, що раніше вважалося цільною монолітною особистістю (як, наприклад, стереотип мужності). Більш того, перехід від масового виробництва товарів таких, як на виробничих підприємствах Форда, та від імперіалістичних моделей глобальних медіапотоків - до виробництва для менших ринків (для ніш), плюс до того поняття демократичності смаку і споживання сьогодні вже не передбачає опору на глобалізаційні тенденції, оскільки ніші-ринки можуть бути інтернаціональними або транснаціональними. Така ситуація знову нас повертає до постмодерну як стану плюралізму і можливості вибору.

Отже, використання терміну постмодерн, хоча і походить від західної інтелектуальної культури, дає можливість альтернативи дискурсу ієрархії і нагляду над «загальною» куль- 
турою, яка асоціюється 3 модернізмом і прискорює дебати феміністських і незахідних критиків. Результат цього - вироблення дискурсу, в якому впевненості великих наративів імперіалістичної західної сучасності може бути кинутий виклик зосередження на різниці в споживанні медіапрактик. Але ці практики необхідно також замінити їх взаємозв'язком 3 великомасштабними детермінантами, що демонструють особливе і локальне. Культурний імперіалізм як ознака глобалізації в цьому контексті повинен розглядатися як феномен гегемонії потужної культурної індустрії з одного боку, і як феномен споживчої практики, пов’язаної з повсякденним вибором в конкретних локальних суспільствах.

Д. Бігнелл наводить приклад медіаінституту MTV як прикладу американського капіталістичного підприємства, мета якого залучити неамериканську музику в американський ринок і стимулювати бажання мати американський продукт за межами США [3, 174]. Медіаінститут MTV міг функціонувати як приклад постмодернової корпорації глобальної медіакультури з доступним каналом у різноманітних культурах і ринках. Це стосувалося не тільки розповсюдження американського або вестерного стилю музики, оскільки інколи екранне відео виникало поза вестерн поп-культурою, але й адресувалося до молодої культури з підтримкою передбачуваних проблем і бажань споживачів, що стало аргументом у напрямку ефекту гомогенізації. Власники MTV, просуваючи власну рекламу, здається, підтримують це такими гаслами: «Один світ, один імідж, один канал!», MTV, який святкує стирання різниці глобального споживацтва. Таким чином, проблема культурного імперіалізму як наслідку глобалізації вирішується на рівні повсякденних практик споживчої культури $[3,174]$.

Гра з ідентичністю, наприклад, медіаікона Мадонна, залучає якомога більше культурних дискурсів, залишаючись одночасно глобальним феноменом медіаіндустрії. Медіакультура використовує, наприклад, рекламу, для представлення речей як об'єктів бажання, символічних і фрагментованих, але одночасно занурених у велику індустрію культурного імперіалізму. Виходячи 3 цього, культурний імперіалізм в дискурсі глобалізації - слід розглядати як явище суб'єктно-обєктне. Тому інтерпретація культури як діяльності з виробництва свідомості, «суб'єктивних форм», у які ми вкладаємо наше життя, це основна мета такого аналізу». Здебільшого в умовах постмодерного дискурсу культури користувачі краще сприймають символічний зміст продукту, ніж функціональний. Важливою передумовою формування моделі поведінки споживачів у сучасних умовах є той факт, що досить часто споживач приймає рішення про купівлю не на основі функціональних можливостей товару, а на основі його символічного змісту. «На прийняття остаточного рішення про вибір одного варіанта з багатьох впливають різні фактори, у тому числі образи, нав'язані споживачеві засобами масової інформації; враження, отримані ним в результаті спостереження життя оточуючих. На таке рішення може навіть вплинути бажання споживача жити в деякому уявному світі, створеному маркетологами» [13].

Досить передбачувану картину дає нам, наприклад, рейтинг вподобання української аудиторії інтернет-провайдера міста Черкас «Маклауд», який надає послуги безкоштовного відеоперегляду кінопродукціï. http:/video.koma.tv. Аналізуючи вподобання глядачів за рейтингом сайту, коментарям, перегляду за останній місяць, ми побачили таку картину:

- за рейтингом сайту перші позиції з 10 фільмів займають: 7 США, 2 СССР, 1 Франція;

- за коментарями з перших 10 фільмів за рейтингом займають: 9 США або США разом з Францією, Великобританією та ін. і 1 Франція;

- $\quad$ за переглядами за місяць 3 перших 10 фільмів: 8 США, 1 Росія, 1 Німеччина.

За рейтингом Internet Movie Database серед 250 найкращих фільмів більшість - це США, потім Свропа, потім Японія. Жодного українського, російського або радянського режисера.

Показово, що кінопропродукція США займає домінуюче місце для інтернет-глядачів 
цього конкретного ресурсу. Така ж картина спостерігається на більшості українських інтернет-сайтах для перегляду фільмів. Слід зазначити, що майже всі продукти культурної індустрії будуть мати приблизно такий самий рейтинг. «Можна погоджуватися з терміном культурний імперіалізм, можна 3 ним сперечатися або заперечувати його взагалі, але факт залишається фактом - зовнішня культурна експансія США, що є частиною їх офіційної та неофіційної зовнішньої культурної політики, не ослабла, і сьогодні є дієвим інструментом поширення американського впливу і забезпечення їх національних інтересів (поряд з інтересами американського великого бізнесу), у зв'язку з чим за традицією носить чималий ідеологічний «заряд» [4].

\section{4. Висновки}

Суб’єктивними аспектами культурної глобалізації вважаємо виробництво дискурсу, в якому великим наративам зроблено виклик різноманітністю практик споживання. Оскільки політика глобалізації передбачає мультикультуралізм, то множинність ідентичностей, спровокована технологіями віртуалізації, спричиняє нові форми культурної взаємодії, дозволяє гру з різними культурними контекстами. Отже, причиною культурного імперіалізму є взаємопроникнення культур як наслідок мультикультурної політики західних держав, що створює ефект самоідентифікації в межах глобального культурного дискурсу. Американська культура в такому випадку виступає як універсальна мова, зрозуміла практично кожному.

Культурний імперіалізм відбувається завдяки «медіаглобалізації», оскільки саме медіакультура $є$ панівною в сучасному культурному дискурсі. Медіа в сучасному соціокультурному середовищі набули глобального значення, технологічно розширили можливості людини. Відмінною рисою сучасних технологій $є$ їх властивість не тільки розширювати можливості людини, а й суттєво впливати на неї, змінюючи сприйняття світу та уявлення про себе.

Виробництво свідомості засобами медіакультури (реклама, кіноіндустрія, виробництво новин, поп-культура) використовує так звані «суб' єктивні форми» повсякдення, у які ми вкладаємо наше життя, для виробництва суспільної згоди на основі технологій фрагментації, мультикультурності, транснкультурних та ін. технологій. Постмодернова гра з ідентичністю, залучення різних культурних форм і образів - це важливий аспект культурного імперіалізму. Суспільна згода - це одна з головних причин перемоги культурного імперіалізму і взагалі тенденцій глобалізації в сучасному світі.

Особливою «магією»є технокультура, що використовує технічні і комунікаційні можливості і досягнення. На рівні локальної культури масові комунікації і медіакультура в умовах постмодернової ситуації, а також плинності і фрагментації постійно створюють і змінюють образи і символи, за якими іде споживач, демонструючи певну символічну і соціальну солідарність.

Грунтуючись на культурологічних підходах до проблеми глобалізації, вважаємо, що в Україні сьогодні панує другий сценарій культурного імперіалізму, який називається «периферійна корупція» - розкладання західної культури на периферійні сегменти в глобальному світі, коли периферійні культури відфільтровують і адаптують під себе глобалізовані культурні продукти.

\section{References}

1. Kravchuk, M. (2003), “Conceptual evolution of globalization theories”, Political management [Politichnij menedzhment], no. 2, pp. 122-136.

2. Udovik, S. (2002), Globalization. Semiotic Approach, Refl-Buk, Moscow, Vakler, Kyiv, 
$461 \mathrm{p}$.

3. Bignell, J. (2001), Postmodern Media Culture, Edinburg University Press, Edinburg, $240 \mathrm{p}$.

4. Filimonov, G. (2012), "The concept of "cultural imperialism" in American political thought", Education. Science. Scientific Personnel [Obrazovanie. Nauka. Nauchnye kadry], no. 1, pp. 181-184.

5. Shiller, G. (1980), Consciousness Manipulators, Mysl, Moscow, 640 p.

6. McPhail, T. (1987), Electronic colonialism: the future of international broadcasting and communication, Sage Publications, $314 \mathrm{p}$.

7. Butyrina, M. (2009), Stereotypes of Mass Consciousness: Peculiarities of Formation and Functioning in the Media Sphere, Slovo, Dnipropetrovsk, 368 p.

8. Krajnikova, T. (2004), Culture of Media Consumption in Ukraine: Current State and Mechanisms of Shaping, Dr. Sc. diss. (social communication), Taras Shevchenko National University of Kyiv, $477 \mathrm{p}$.

9. Featherstone, M., Lash, S. \& Robertson R. (Eds.) (2008), Global Modernities, NikaCentr, Kyiv, 385 p.

10. Appadurai, A. (1996), Modernity at Large: Cultural Dimensions of Globalization, University of Minnesota Press, Minneapoli, $330 \mathrm{p}$.

11. Tapscott, D. \& Williams A.D. (2006), Wikinomics: How Mass Collaboration Changes Everything, Portfolio, $324 \mathrm{p}$.

12. Giddens, A. (1990), The Consequences of Modernity, Stanford University Press, Stanford, $188 \mathrm{p}$.

13. Draganchuk, L.S. (2011), Consumer Behavior: a Textbook, INFRA-M, Moscow, 192 p.

\section{Список джерел}

1. Кравчук М. Концептуальна еволюція теорій глобалізації / М. Кравчук // Політичний менеджмент : наук. журнал / Голов. ред. Ю. Ж. Шайгородський. - 2003. - №2. - С.122136.

2. Удовик С. Глобализация. Семиотические подходы / С. Удовик. - М. : «Рефл-бук» ; К. : «Ваклер», 2002. -461 с.

3. Bignell J. Postmodern Media Culture / J. Bignell. - Edinburg : Edinburg University Press, 2001. $-240 \mathrm{p}$.

4. Филимонов Г. Концепция «культурного империализма» в американской политической мысли / Г. Филимонов // Образование. Наука. Научные кадры. - 2012. - № 1. C.181-184.

5. Шиллер Г. Манипуляторы сознанием / Г. Шиллер. - М. : Мысль, 1980. - 640 с.

6. McPhail T. Electronic colonialism: the future of international broadcasting and communication / T. McPhail. - Sage Publications, 1987. - 314 p.

7. Бутиріна М. Стереотипи масової свідомості: особливості формування та функціонування у медіасередовищі : монографія / М Бутиріна. - Дніпропетровськ : Видавництво «Слово», 2009. - 368 с.

8. Крайнікова Т. Культура медіаспоживання в Україні: актуальний стан і механізми формування: дис. ... док. наук із соц.. ком : 27.00 .01 - теорія та історія соціальних комунікацій/ Т. Крайнікова ; КНУ ім. Т. Шевченка. - Київ, 2004. - 477 с.

9. Глобальні модерності / За ред. Майка Фезерстоуна, Скота Леша та Роланда Робертсона. - Київ: Ніка-Центр, 2008. - 385 с.

10. Appadurai A. Modernity at Large: Cultural Dimensions of Globalization / A. Appadurai. - Minneapolis : University of Minnesota Press, 1996. - 330 p.

11. Тапскотт Д., Уильямс Э.Д. Викиномика. Как массовое сотрудничество изменяет 


\section{ISSN 2312-5160}

все / Д. Тапскотт, Э.Д. Уильямс. - М.: Best Business Books, 2009. - 392 с.

12. Giddens A. The Consequences of Modernity / A. Giddens . - Stanford: Stanford University Press, 1990. - 188 p.

13. Драганчук Л. С. Поведение потребителей: учеб. пособие / Л. С. Драганчук. - М. : ИНФРА-М, 2011. - 192 с. 